\title{
-
}

SYSTEMATIC REVIEW

\section{Evaluation of marginal bone loss of dental implants with internal or external connections and its association with other variables: A systematic review}

\author{
Rodrigo Antonio de Medeiros, DDS, MSc, ${ }^{a}$ Eduardo Piza Pellizzer, MS, PhD, ${ }^{b}$ \\ Aljomar José Vechiato Filho, DDS, MS, ${ }^{c}$ Daniela Micheline dos Santos, MS, PhD, ${ }^{d}$ \\ Emily Vivianne Freitas da Silva, DDS, MSc, ${ }^{e}$ and Marcelo Coelho Goiato, MS, PhD ${ }^{f}$
}

Since their introduction in the 1960s and 1970s, osseointegrated dental implants have been used worldwide to rehabilitate patients with partial or complete edentulism. ${ }^{1}$ The evaluation of bone stability is essential to ensure optimal long-term results of osseointegrated implants, because excessive bone loss can result in periimplantitis, ${ }^{2}$ which can lead to eventual implant loss. Additionally, the loss of marginal bone height can change the surrounding soft tissue architecture, resulting in the loss of interdental papilla and causing esthetic and phonetic changes and food impaction. ${ }^{3}$ Decreases in inflammatory reactions, load concentrations, and bacterial leakage at the implantabutment interface are closely associated with marginal bone loss. ${ }^{4,5}$

\begin{abstract}
Statement of problem. Different factors can influence marginal bone loss around dental implants, including the type of internal and external connection between the implant and the abutment. The evidence needed to evaluate these factors is unclear.

Purpose. The purpose of this systematic review was to evaluate marginal bone loss by radiographic analysis around dental implants with internal or external connections.

Material and methods. A systematic review was conducted following the criteria defined by the Preferred Reporting Items for Systematic Reviews and Meta-Analyses (PRISMA). Initially, a population, intervention, comparison, and outcome(s) (PICO) question was defined: does the connection type (internal or external) influence marginal bone loss in patients undergoing implantation? An electronic search of PubMed/MEDLINE and Scopus databases was performed for studies in English language published between January 2000 and December 2014 by 2 independent reviewers, who analyzed the marginal bone loss of dental implants with an internal and/or external connection.
\end{abstract}

Results. From an initial screening yield of 595 references and after considering inclusion and exclusion criteria, 17 articles were selected for this review. Among them, 10 studies compared groups of implants with internal and external connections; 1 study evaluated external connections; and 6 studies analyzed internal connections. A total of 2708 implants were placed in 864 patients. Regarding the connection type, 2347 implants had internal connections, and 361 implants had external connections. Most studies showed lower marginal bone loss values for internal connection implants than for external connection implants.

Conclusions. Osseointegrated dental implants with internal connections exhibited lower marginal bone loss than implants with external connections. This finding is mainly the result of the platform switching concept, which is more frequently found in implants with internal connections. (J Prosthet Dent 2016;116:501-506)

\footnotetext{
apostgraduate student, Aracatuba Dental School, São Paulo State University, São Paulo, Brazil.

bProfessor, Aracatuba Dental School, São Paulo State University, São Paulo, Brazil.

${ }^{\mathrm{c}}$ Postgraduate student, Aracatuba Dental School, São Paulo State University, São Paulo, Brazil.

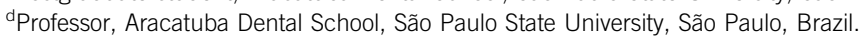

ePostgraduate student, Aracatuba Dental School, São Paulo State University, São Paulo, Brazil.

fProfessor, Aracatuba Dental School, São Paulo State University, São Paulo, Brazil.
} 


\section{Clinical Implications}

The choice of internal or external connection implants may influence marginal bone loss, but no current consensus has been published as to the best treatment option for minimizing marginal bone loss. Platform switching may be more important to the preservation of marginal bone than the connection type itself.

Several factors can influence marginal bone loss around dental implants, including patient characteristics (smoking and hygiene deficiency or parafunctional habits), ${ }^{6}$ prosthesis characteristics (retention method and number of elements), and dental implant characteristics (diameter, surface treatment, and connection type). ${ }^{7,8}$

Various dental implants with different internal and external connection types are available. These connections and how they relate to the implant abutment may influence marginal bone loss. ${ }^{7}$ The abutment and the implant can be of equal diameters, or an abutment with a narrower diameter (the platform switching concept) can be used. ${ }^{7}$ The connection between the abutment and implant is related to the formation of microgaps, bacterial leakage, micromovements of the abutments, and alteration of biologic width formation, all of which may cause higher or lower marginal bone loss. ${ }^{9}$

Studies have compared the marginal bone loss of several types of implants by considering implant macrodesign surface treatment, and installation depth. However, few studies have evaluated the marginal bone loss around implants by considering the connection type. Additionally, the authors are unaware of any systematic review that has evaluated the influence of implant connections in bone loss. This systematic review aimed to evaluate the marginal bone loss around dental implants by considering the implant connection type.

\section{MATERIAL AND METHODS}

A systematic review was conducted following the criteria defined by Preferred Reporting Items for Systematic Reviews and Meta-Analyses (PRISMA) criteria. ${ }^{10}$ Initially, a population, intervention, comparison, and outcome(s) (PICO) question was defined: does the connection type (internal or external) influence marginal bone loss in patients submitted to implant installation? An electronic search of the PubMed/MEDLINE and Scopus databases was performed for studies published in English between January 2000 and December 2014 by 2 independent reviewers (R.A.M. and A.J.V.F.). Any disagreement regarding the inclusion of an article was resolved by discussion or, in the case of unresolved conflicts, by a third reviewer (M.C.G.). Articles related to marginal bone loss around dental implants with internal or external connections were selected by using the Medical Subject Headings (MeSH) keywords "dental implant AND internal connection" and "dental implant AND external connection." Initially, titles and abstracts were read, and after inclusion and exclusion criteria were considered, the full texts were selected for reading and final selection.

Criteria for inclusion were that studies were published in English, they evaluated the marginal bone loss around dental implants with internal or external connections, they evaluated the platform switching concept, that they were randomized, prospective, and retrospective studies.

Studies were excluded because they were not written in English, or they duplicated studies; they were animal or in vitro studies, case reports, interviews, or comments and questionnaire studies, or literature or systematic reviews; they evaluated surgical techniques such as maxillary sinus lifting, implant installation in 1 or 2 stages, new surgical kits and bone grafts; they evaluated implant surface treatments; they assessed abutment height, marginal adaptation and angulation; they did not report marginal bone loss or reported insufficient data concerning the implant connection used; and they assessed nonoral implants.

The factors extracted from the selected studies and analyzed were first author and year, implant connection type, profile of the participants (average age, number of men and women, number of smokers [over 10 cigarettes per day]), quantity and characteristics of the implants (implant diameter/length and manufacturer), arch where the implant was placed, prosthesis type, and bone loss. When the connection type was not described in the study, a search of the implant manufacturer's Website reported in the article was was performed. When the connection type or commercial brand of the implant used was not found, the article was excluded.

\section{RESULTS}

A publications search using the keyword phrase "dental implant AND internal connection" yielded 183 articles in the PubMed/MEDLINE database and 195 articles in the Scopus database. After removing duplicated articles and considering the inclusion and exclusion criteria, 16 articles $(\kappa=0.94)$ remained. For the keyword phrase "dental implant AND external connection," 105 articles were obtained from the PubMed/MEDLINE database and 112 articles from the Scopus database. After the exclusion of duplicated articles and application of inclusion and exclusion criteria, 12 articles were included for full text reading $(\kappa=0.92)$. After the union of both search results, 17 articles were selected for this review (Fig. 1). Reasons for the exclusion of 2 articles are listed in Table 1 . The number of randomized clinical trials that 


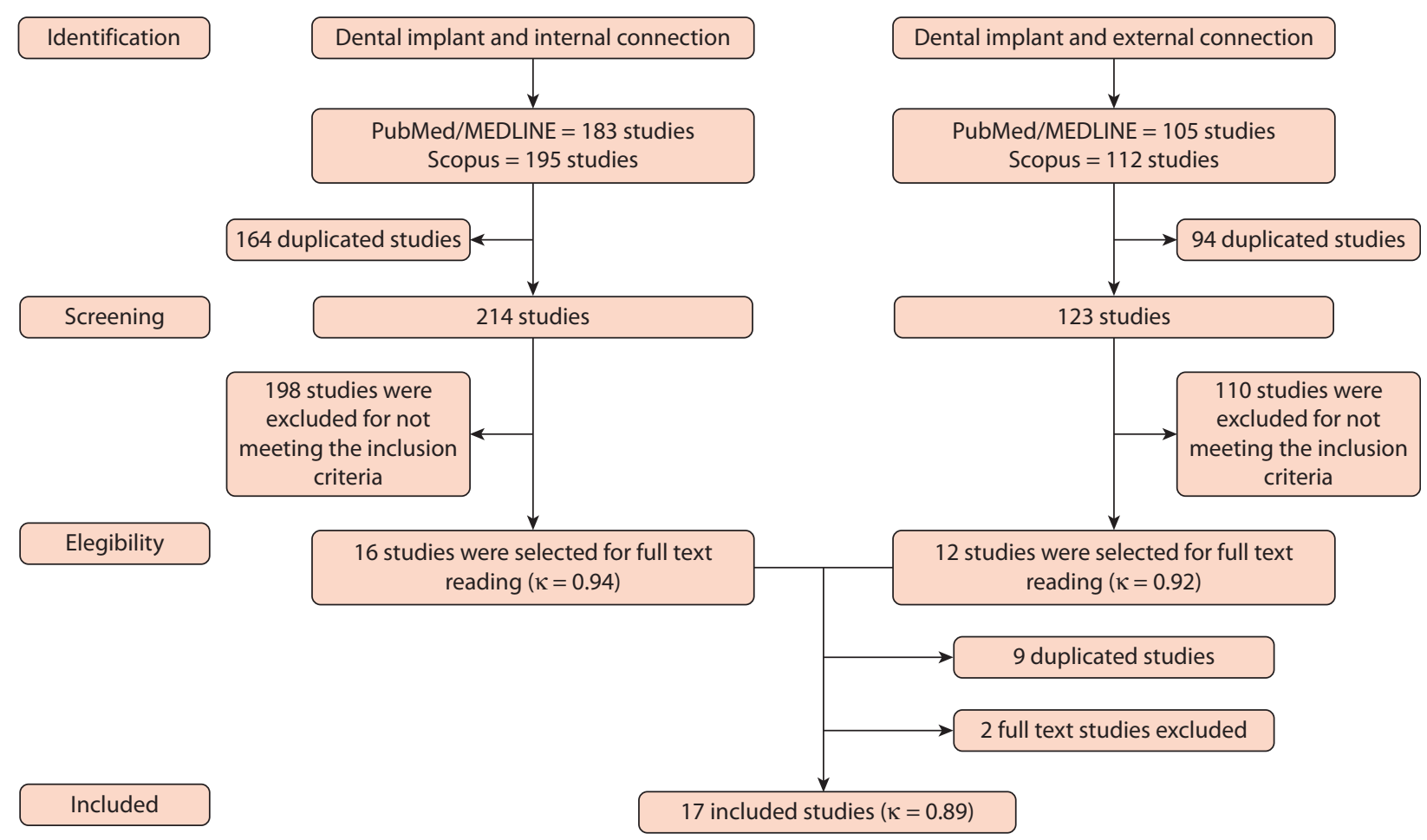

Figure 1. Literature screening process.

compared marginal bone loss with internal and external connections was small. Because data were insufficient to conduct a meta-analysis, they was critically analyzed.

Supplemental Tables 1 to 3 show the results obtained after the selected studies were read. Supplemental Table 1 and Table 2 show the results for studies that compared internal and external connections. Supplemental Table 2 shows studies that evaluated external connections, and Supplemental Table 3 lists data of studies that analyzed internal connections.

Supplemental Table 4 shows the marginal bone loss in different follow-up periods reported in the studies. Oliva et $\mathrm{al}^{11}$ and Jo et $\mathrm{al}^{12}$ evaluated only 1 follow-up period, and those data are presented in Supplemental Table 2. Canullo et $\mathrm{al}^{8}$ did not report marginal bone loss at 6 and 12 months, showing the results only on a graph with approximate values.

The marginal bone loss measured in the studies demonstrates that, over the years, internal connection implants have lower values of bone resorption than external connection implants. Among 10 studies that compared groups with both connection types, 5 studies $^{4,7,8,13,14}$ showed that internal connections exhibited lower values of marginal bone loss, with statistically significant difference. Three other articles ${ }^{15-17}$ showed no statistical difference between the connections, 1 study ${ }^{18}$ presented statistically better performance of external connections, and 1 study ${ }^{11}$ did not report statistical analysis, but the results of bone loss were lower for internal connections.
Table 1. Reasons for excluding articles after full text reading

\begin{tabular}{ll}
\hline Study & \multicolumn{1}{c}{ Reason for Exclusion } \\
\hline Jo et al ${ }^{12} 2013$ & Insufficient data concerning implant connection used \\
\hline Drago et al ${ }^{42} 2006$ & Insufficient data concerning implant connection used \\
\hline
\end{tabular}

Additionally, the results demonstrated that implants with platform switching (Supplemental Tables 1-3), regardless of the connection type used, showed reduced bone resorption rates compared with the use of an abutment diameter equal to the implant platform. All internal connection implants used the platform switching concept, except for a group in the study by Pieri et al, ${ }_{1}^{19}$ where abutments with the same diameter of the implant were placed. For studies using external connection implants, only the study by Vandeweghe and De Bruyn $^{6}$ used this approach, installing implants with the platform switching concept on one side and the nonswitched concept on the other.

In the 17 studies, a total of 2708 implants were placed in 864 patients (mean age of 43.73 years). The implants were marketed by 10 different companies. Regarding the connection type, 2347 implants had internal connections, and 361 implants had external connections.

Implant diameters ranged from $3.5 \mathrm{~mm}$ to $7 \mathrm{~mm}$, and most studies (12 articles) used implants with the conventional platform $(3.9-4.5 \mathrm{~mm})$. Among the external connection implants, $14.54 \%$ had diameters between 3.5 and $3.8 \mathrm{~mm}, 65.76 \%$ had diameters between 3.9 and $4.5 \mathrm{~mm}$, and $19.7 \%$ had diameters larger than $4.5 \mathrm{~mm}$. 
Table 2. Studies comparing the mean values of marginal bone loss around implants with internal and external connections

\begin{tabular}{|c|c|c|}
\hline Author & $\begin{array}{c}\text { Internal } \\
\text { connection }(\mathrm{mm})\end{array}$ & $\begin{array}{c}\text { External } \\
\text { connection }(\mathrm{mm})\end{array}$ \\
\hline Crespi et al, $^{15} 2009$ & 0.73 & 0.78 \\
\hline Kielbassa et al, ${ }^{17} 2009$ & 0.79 & 0.64 \\
\hline Peñarrocha-Diago et al, ${ }^{14} 2013$ & 0.12 & 0.38 \\
\hline Oliva et al, ${ }^{11} 2012$ & 0.53 & 0.84 \\
\hline Arnhart et al, ${ }^{18} 2012$ & 0.87 & 0.16 \\
\hline Koo et al, $^{7} 2012$ & 0.07 & 0.29 \\
\hline Canullo et al $^{8} 2012$ & 0.56 & 1.63 \\
\hline Lin et $\mathrm{al}_{,}^{16} 2013$ & 0.35 & 0.32 \\
\hline Pozzi et al, ${ }^{4} 2014$ & 0.51 & 1.1 \\
\hline Pozzi et al, ${ }^{13} 2014$ & 0.67 & 1.24 \\
\hline
\end{tabular}

Among the internal connection implants, $17.92 \%$ had diameters between 3.5 and $3.8 \mathrm{~mm}, 62.02 \%$ had diameters between 3.9 and $4.5 \mathrm{~mm}$, and $20.06 \%$ had diameters larger than $4.5 \mathrm{~mm}$.

Implant length ranged from 8 to $16 \mathrm{~mm}$. Shorter implants were not used in the studies. Among the external connection implants, $4.85 \%$ had lengths between 8 and $9 \mathrm{~mm}, 94.55 \%$ were between 10 and $13 \mathrm{~mm}$, and $0.60 \%$ had implants longer than $15 \mathrm{~mm}$. For the internal connection implants, $0.57 \%$ had lengths between 8 and $9 \mathrm{~mm}, 90.19 \%$ were between 10 and $13 \mathrm{~mm}$, and $9.24 \%$ had implants longer than $13 \mathrm{~mm}(14,15$, and $16 \mathrm{~mm}$ ). Four studies did not report diameter and length of the implants. $2,12,19,20$

Characteristics of the prosthesis used in the included studies are described in Tables 2 to 4 . Types of prostheses varied from single crowns to complete-arch prostheses, both implant-supported and implant-retained prostheses (bar overdentures or stud attachment overdentures). Of the screwed and cemented prostheses, the latter were more prevalent.

\section{DISCUSSION}

All studies selected for this systematic review evaluated bone loss through radiographic analysis, as the vertical differences between implant platforms and first bone contacts with implant surfaces. This analysis is widely used but has limitations. The evaluation is performed only in the mesial and distal sites of the implant, disregarding any changes in bone profile that occur in the buccal and lingual sites of the implant. ${ }^{21}$ Further studies should be performed to evaluate marginal bone loss by using a 3-dimensional imaging method to assess the full bone profile around dental implants.

Most studies showed marginal bone loss values for internal connection implants that were lower than those for external connection implants. $4,7,8,11,13,14$ However, only 2 studies ${ }^{7,8}$ had a similar macrodesign and surface treatment of the dental implant, differentiating between the groups only by connections. Nevertheless, other factors, related mainly related to participants, may have influenced the results of Koo et al. ${ }^{7}$ Additionally, although Canullo et $\mathrm{al}^{8}$ had placed implants with both types of connections in the same participants, they did not standardize the distance between the implants and did not report whether the procedure was performed by a single surgeon. Additionally, having splinted prostheses may have influenced the results.

Limitations were frequently found in the studies because many factors can influence marginal bone loss. Factors are related to implants (diameter and length, neck design, surface treatment, angulation, immediate or delayed loading, distance between adjacent teeth or implants, installation depth), to prostheses (number of teeth rehabilitated by the prosthesis and their retention, abutment type, antagonist arch), and to the patient (bone type, region needing rehabilitation, parafunctional habits, patient hygiene, smoking habits, systemic factors). ${ }^{6}$ However, overcoming those limitations is difficult because of the many different implants on the market and because finding participants with identical profiles who need the same type of prosthesis is difficult. These limitations also influence the differing bone loss values among studies.

Despite these limitations, the majority of studies $(n=5)$ that compared both types of connections showed that internal connection implants reduced marginal bone loss. Those authors $4,7,8,13,14$ concluded that the platform switching concept (abutment diameter smaller than implant diameter), which is generally used for implants with this connection type, was largely responsible. ${ }^{7}$ This concept is suitable because the implant-abutment interface is distanced from the bone crest, resulting in the dissipation of load concentration, abutment micromovements, and, especially, bacterial colonization in a more distant region of the bone. ${ }^{14}$

Load concentration is located mainly in the implantabutment interface, reducing the stress concentration of internal connection implants that use the platform switching concept in the periimplant bone region. ${ }^{22,23}$ Additionally, the use of this restoration method decreases abutment micromovements ${ }^{13}$ during functional loading, preserving the relationship between the periimplant tissue and the implant and reducing bacterial leakage. ${ }^{24}$ Platform switching also contributes to the reestablishment of the biological width. ${ }^{7}$ The biological width acts against bacterial leakage and is closely related to bone remodeling. ${ }^{13,16}$ Corroborating the importance of the platform switching concept, Pieri et al ${ }^{19}$ compared 2 internal connection implants, varying the abutment diameter with one smaller than the implant platform and the other with the same diameter. Lower statistically significant values were verified for groups with platform switching.

Although the platform switching concept is used more for internal connection implants, resulting in lower 
marginal bone values, it can also be used for external connections. ${ }^{6}$ Vandeweghe and Bruyn $^{6}$ compared external connection implants with platform switching on one side (test group) and with the conventional platform on the other side (control group), obtaining smaller bone loss values in the side with platform switching. In this study, several factors that can influence the outcome were removed, since both groups had the same soft and hard tissues properties, surgical protocol, and patient health and hygiene conditions. ${ }^{6}$ The combination of platform switching and external connection implants demonstrated good results, ${ }^{6}$ which suggests that, regardless of the connection type (internal or external), this concept can be used. Platform switching may be more important to the preservation of marginal bone than the connection type itself.

In vitro studies indicate that the platform switching concept reduces the stress on the implant neck area in both connection types. ${ }^{25-28}$ However, the loads are more concentrated in the implant-abutment interface, which may cause abutment screw deformation or loosening. ${ }^{23}$

Only 1 study found lower marginal bone loss values with external connection implants when compared with those with internal connections. ${ }^{18}$ These authors hypothesized that the implant used had an abutment with a tight frictional retention, complicating its handling. Thus, many centers decided to remain with the initial abutment during the treatment, keeping the transgingival interface intact throughout the course of the study. Another factor that may have influenced the results was the geometry of the implant, which has a narrower neck design than the implant body and may favor beneficial bone remodeling.

Other factors influencing marginal bone loss, regardless of the connection type used, are the types of prosthesis retention, smoking habits, distance between implants, and implant diameter and length. ${ }^{29}$

Little consensus on the optimal prosthesis retention system has been reached. ${ }^{30}$ Some studies did not demonstrate differences between cemented and screwed prostheses, $^{31-33}$ but other studies showed lower bone loss values for screwed prostheses ${ }^{34}$ or cemented prostheses. $^{35}$ However, excess cement must be avoided, ${ }^{36}$ especially when it is located subgingivally, ${ }^{30}$ which may result in periimplant alterations and bone loss. ${ }^{37}$ Most articles analyzed in the present systematic review used cemented, implant-supported prostheses.

A few studies evaluated marginal bone loss in smokers (over 10 cigarettes per day). ${ }^{11,19}$ However, those authors did not show differences between smokers and nonsmokers. The other studies included smokers or patients who consumed more than 10 cigarettes per day in the exclusion criteria. Smoking habits can negatively influence marginal bone loss, especially when related to the patient's hygiene habits. ${ }^{38}$ Although Takamiya et $\mathrm{al}^{39}$ found that smoking cannot be an absolute contraindication to dental implant treatment, smokers should be advised of the greater risks of implant failure.

In the present review, a few studies assessed oral hygiene habits ${ }^{14}$ or performed periodontal treatment before implant installation. ${ }^{20,40}$ Meyle et $\mathrm{a}^{40}$ evaluated bone loss with internal connection implants in patients with a history of chronic periodontitis, concluding that the results are satisfactory if infection is properly controlled and periodontal attachment levels are maintained.

Only 1 study analyzed implant diameter and length as factors in bone loss. ${ }^{14}$ The authors observed that a reduction in bone loss occurred with the increase in implant diameter and length. Only 1 study evaluated the distance between implants ${ }^{12}$ with no differences in marginal bone loss between internal connection implants placed with a interimplant distance smaller or larger than $3 \mathrm{~mm}$. Regarding implant depth, most studies installed implants at the crestal bone level. ${ }^{4-8,13,14,16,40}$ Published reports of clinical studies that assessed this condition are scarce. When the implant was not loaded functionally, no differences were found in bone loss between implants placed subcrestally or crestally. ${ }^{41}$ When the implant was in function, bone might form on the platform of implants placed subcrestally, resulting in better clinical outcomes after 1 year of loading than for implants placed crestally. ${ }^{21}$

Marginal bone loss is not dependent on only 1 factor, such as the connection type, but on several factors combined that promote bone maintenance or loss. However, considering the limitations of clinical trials and of this systematic review, internal connections performed better than external connections, mainly because of the platform switching concept used. Since some studies showed no statistically significant difference between the connection types and since others concluded that the internal connections have greater stability in bone remodeling, internal connections should be indicated for clinical use when only the marginal bone loss factor is considered.

\section{CONCLUSIONS}

Osseointegrated dental implants with internal connections demonstrated lower marginal bone loss values when compared with implants with external connections. This is mainly because of the platform switching concept, which is more frequently used in implants with internal connections.

\section{REFERENCES}

1. Gracis S, Michalakis K, Vigolo P, Vult von Steyern P, Zwahlen M, Sailer I Internal vs. external connections for abutments/reconstructions: a systematic review. Clin Oral Implants Res 2012;23(suppl 6):202-16.

2. Chou CT, Morris HF, Ochi S, Walker L, DesRosiers D. AICRG. Part II: Crestal bone loss associated with the Ankylos implant: loading to 36 months. J Oral Implantol 2004;30:134-43. 
3. Kolte AP, Kolte RA, Mishra PR. Dimensional influence of interproximal areas on existence of interdental papillae. J Periodontol 2014:85:795-801.

4. Pozzi A, Agliardi E, Tallarico M, Barlattani A. Clinical and radiological outcomes of two implants with different prosthetic interfaces and neck configurations: randomized, controlled, split-mouth clinical trial. Clin Implant Dent Relat Res 2014:16:96-106.

5. Calvo-Guirado J, Gómez-Moreno G, Aguilar-Salvatierra A, Guardia J, Delgado-Ruiz RA, Romanos GE. Marginal bone loss evaluation around immediate non-occlusal microthreaded implants placed in fresh extraction sockets in the maxilla: a 3-year study. Clin Oral Implants Res 2015 Jul;26: $761-7$.

6. Vandeweghe S, De Bruyn H. A within-implant comparison to evaluate the concept of platform switching: a randomised controlled trial. Eur J Ora Implantol 2012;5:253-62.

7. Koo KT, Lee EJ, Kim JY, Seol YJ, Han JS, Kim TI, et al. The effect of interna versus external abutment connection modes on crestal bone changes around dental implants: a radiographic analysis. J Periodontol 2012;83:1104-9.

8. Canullo L, Rosa JC, Pinto VS, Francischone CE, Gotz W. Inward-inclined implant platform for the amplified platform-switching concept: 18-month follow-up report of a prospective randomized matched-pair controlled trial. Int J Oral Maxillofac Implants 2012;27:927-34.

9. Herrero-Climent M, Romero Ruiz MM, Diaz-Castro CM, Bullon P, Rios-Santos JV. Influence of two different machined-collar heights on cresta bone loss. Int J Oral Maxillofac Implants 2014;29:1374-9.

10. Moher D, Liberati A, Tetzlaff I, Altman DG. Preferred reporting items for systematic reviews and meta-analyses: the PRISMA statement. Int J Surg 2010;8:336-41.

11. Oliva J, Oliva X, Oliva JD. All-on-three delayed implant loading concept for the completely edentulous maxilla and mandible: a retrospective 5-year follow-up study. Int J Oral Maxillofac Implants 2012;27:1584-92.

12. Jo DW, Yi YJ, Kwon MJ, Kim YK. Correlation between interimplant distance and crestal bone loss in internal connection implants with platform switching. Int J Oral Maxillofac Implants 2014;29:296-302.

13. Pozzi A, Tallarico M, Moy PK. Three-year post-loading results of a randomised, controlled, split-mouth trial comparing implants with different prosthetic interfaces and design in partially posterior edentulous mandibles. Eur Oral Implantol 2014;7:47-61.

14. Penarrocha-Diago MA, Flichy-Fernandez AJ, Alonso-Gonzalez R, Penarrocha-Oltra D, Balaguer-Martinez J, Penarrocha-Diago M. Influence of implant neck design and implant-abutment connection type on peri-implant health Radiological study. Clin Oral Implants Res 2013;24:1192-200.

15. Crespi R, Cappare P, Gherlone E. Radiographic evaluation of marginal bon levels around platform-switched and non-platform-switched implants used in an immediate loading protocol. Int J Oral Maxillofac Implants 2009;24: 920-6.

16. Lin MI, Shen YW, Huang HL, Hsu JT, Fuh LJ. A retrospective study of implant-abutment connections on crestal bone level. J Dent Res 2013;92: 202s-7s.

17. Kielbassa AM, Martinez-de Fuentes R, Goldstein M, Arnhart C, Barlattani A Jackowski J, et al. Randomized controlled trial comparing a variable-thread novel tapered and a standard tapered implant: interim one-year results. J Prosthet Dent 2009:101:293-305.

18. Arnhart C, Kielbassa AM, Martinez-de Fuentes R, Goldstein M, Jackowski J, Lorenzoni M, et al. Comparison of variable-thread tapered implant designs to a standard tapered implant design after immediate loading. A 3-year multicentre randomised controlled trial. Eur J Oral Implantol 2012;5:123-36.

19. Pieri F, Aldini NN, Marchetti C, Corinaldesi G. Influence of implantabutment interface design on bone and soft tissue levels around immediatel placed and restored single-tooth implants: a randomized controlled clinical trial. Int J Oral Maxillofac Implants 2011;26:169-78.

20. Gultekin BA, Gultekin P, Leblebicioglu B, Basegmez C, Yalcin S. Clinical evaluation of marginal bone loss and stability in two types of submerged dental implants. Int J Oral Maxillofac Implants 2013;28:815-23.

21. Koutouzis T, Neiva R, Nonhoff J, Lundgren T. Placement of implants with platform-switched Morse taper connections with the implant-abutmen interface at different levels in relation to the alveolar crest: a short-term (1-year) randomized prospective controlled clinical trial. Int J Oral Maxillofac Implants 2013;28:1553-63.

22. Liu S, Tang C, Yu J, Dai W, Bao Y, Hu D. The effect of platform switching on stress distribution in implants and periimplant bone studied by nonlinea finite element analysis. J Prosthet Dent 2014:112:1111-8.

23. Maeda Y, Miura J, Taki I, Sogo M. Biomechanical analysis on platform switching: is there any biomechanical rationale? Clin Oral Implants Res 2007;18:581-4.
24. Steinebrunner L, Wolfart S, Bossmann K, Kern M. In vitro evaluation of bacterial leakage along the implant-abutment interface of different implant systems. Int J Oral Maxillofac Implants 2005;20:875-81.

25. Yang TC, Maeda Y. The biomechanical effect of platform switching on external- and internal-connection implants. Int J Oral Maxillofac Implants 2013;28:143-7.

26. Sivolella S, Guazzo R, Bressan E, Berengo M, Stellini E. Platform switching on wide-diameter external hex implants: a finite element analysis. J Clin Exp Dent 2013;5:e77-82

27. Gurgel-Juarez NC, de Almeida EO, Rocha EP, Freitas AC Jr, Anchieta RB, de Vargas LC, et al. Regular and platform switching: bone stress analysis varying implant type. J Prosthodont 2012;21:160-6.

28. Sahabi M, Adibrad M, Mirhashemi FS, Habibzadeh S. Biomechanical effects of platform switching in two different implant systems: a three-dimensional finite element analysis. J Dent (Tehran) 2013;10:338-50.

29. Monje A, Suarez F, Galindo-Moreno P, Garcia-Nogales A, Fu JH, Wang HL. A systematic review on marginal bone loss around short dental implants $(<10$ $\mathrm{mm}$ ) for implant-supported fixed prostheses. Clin Oral Implants Res 2014;25: 1119-24.

30. Linkevicius T, Vindasiute E, Puisys A, Linkeviciene L, Maslova N, Puriene A. The influence of the cementation margin position on the amount of undetected cement. A prospective clinical study. Clin Oral Implants Res 2013;24: 71-6.

31. Crespi R, Cappare P, Gastaldi G, Gherlone EF. Immediate occlusal loading of full-arch rehabilitations: screw-retained versus cement-retained prosthesis. An 8-year clinical evaluation. Int J Oral Maxillofac Implants 2014;29:1406-11.

32. Vigolo P, Givani A, Majzoub Z, Cordioli G. Cemented versus screw-retained implant-supported single-tooth crowns: a 4-year prospective clinical study. Int J Oral Maxillofac Implants 2004;19:260-5.

33. Vigolo P, Mutinelli S, Givani A, Stellini E. Cemented versus screw-retained implant-supported single-tooth crowns: a 10-year randomised controlled trial. Eur J Oral Implantol 2012;5:355-64.

34. Weber HP, Kim DM, Ng MW, Hwang JW, Fiorellini JP. Peri-implant softtissue health surrounding cement- and screw-retained implant restorations: a multi-center, 3-year prospective study. Clin Oral Implants Res 2006:17:375-9.

35. Nissan J, Narobai D, Gross O, Ghelfan O, Chaushu G. Long-term outcome of cemented versus screw-retained implant-supported partial restorations. Int J Oral Maxillofac Implants 2011;26:1102-7.

36. Korsch M, Walther W. Peri-implantitis associated with type of cement: a retrospective analysis of different types of cement and their clinical corre lation to the peri-implant tissue. Clin Implant Dent Relat Res 2014;17: e434-43.

37. Chee WW, Duncan J, Afshar M, Moshaverinia A. Evaluation of the amount of excess cement around the margins of cement-retained dental implant restorations: the effect of the cement application method. J Prosthet Dent 2013;109:216-21.

38. Lindquist LW, Carlsson GE, Jemt T. Association between marginal bone loss around osseointegrated mandibular implants and smoking habits: a 10-year follow-up study. J Dent Res 1997;76:1667-74.

39. Takamiya AS, Goiato MC, Gennari Filho H. Effect of smoking on the survival of dental implants. Biomed Pap Med Fac Univ Palacky Olomouc Czech Repub 2014;158:650-3.

40. Meyle J, Gersok G, Boedeker RH, Gonzales JR. Long-term analysis of osseointegrated implants in non-smoker patients with a previous history of periodontitis. J Clin Periodontol 2014:41:504-12.

41. Palaska I, Tsaousoglou P, Vouros I, Konstantinidis A, Menexes G. Influence of placement depth and abutment connection pattern on bone remodeling around 1-stage implants: a prospective randomized controlled clinical trial. Clin Oral Implants Res 2016;27:e47-56.

42. Drago CJ, Lazzara RJ. Immediate occlusal loading of Osseotite implants in mandibular edentulous patients: a prospective observational report with 18 month data. J Prosthodont 2006:15:187-94.

\section{Corresponding author:}

Dr Marcelo Coelho Goiato

Aracatuba Dental School

Department of Dental Materials and Prosthodontics

José Bonifácio, 1193 Vila Mendonça 16015-050

Aracatuba, São Paulo

BRAZIL

Email: goiato@foa.unesp.br

Copyright (C) 2016 by the Editorial Council for The Journal of Prosthetic Dentistry. 
Supplemental Table 1. Data collected from studies evaluating marginal bone loss around implants with internal and external connections

\begin{tabular}{|c|c|c|c|c|c|c|c|c|c|c|c|}
\hline Study & $\begin{array}{c}\text { Type of } \\
\text { Connection }\end{array}$ & $\begin{array}{c}\text { Average } \\
( \pm \text { SD) age }\end{array}$ & $\begin{array}{c}\text { Males/ } \\
\text { Females }\end{array}$ & $\begin{array}{c}\text { Number } \\
\text { of Smokers } \\
(>10 \\
\text { Cigarettes/D) }\end{array}$ & $\begin{array}{l}\text { Number } \\
\text { of Implants }\end{array}$ & $\begin{array}{c}\text { Diameter/ } \\
\text { Length }(\mathbf{m m})\end{array}$ & Arch & Mfr & $\begin{array}{c}\text { Prosthesis } \\
\text { type }\end{array}$ & $\begin{array}{l}\text { Prothesis } \\
\text { retention }\end{array}$ & $\begin{array}{c}\text { Mean Bone } \\
\text { Loss }( \pm \text { SD) } \\
(\mathrm{mm}) / \\
\text { Follow-up } \\
\text { Period } \\
(\mathrm{mo})\end{array}$ \\
\hline \multirow[t]{2}{*}{$\begin{array}{l}\text { Crespi } \\
\text { et } \mathrm{al}^{15} \\
2009 \\
\end{array}$} & $\begin{array}{l}\text { External: } \\
\text { hexagon }\end{array}$ & 48.7 & $18 / 27$ & 0 & 34 & 3.8 and $5 / 13$ & $\begin{array}{l}\text { Maxilla and } \\
\text { mandible }\end{array}$ & $\begin{array}{l}\text { Sweden \& } \\
\text { Martina }\end{array}$ & $\begin{array}{l}\text { Provisional } \\
\text { acrylic resin } \\
\text { prosthesis }\end{array}$ & Cemented & $\begin{array}{c}0.78 \\
( \pm 0.45) / 24\end{array}$ \\
\hline & $\begin{array}{l}\text { Internal: Morse } \\
\text { taper }\end{array}$ & & & 0 & 30 & 4.5 and $5.5 / 14$ & $\begin{array}{l}\text { Maxilla and } \\
\text { mandible }\end{array}$ & $\begin{array}{l}\text { Ankylos- } \\
\text { Dentsply }\end{array}$ & $\begin{array}{l}\text { Provisional } \\
\text { acrylic resin } \\
\text { prosthesis }\end{array}$ & Cemented & $\begin{array}{c}0.73 \\
( \pm 0.52) / 24\end{array}$ \\
\hline \multirow[t]{2}{*}{$\begin{array}{l}\text { Kielbassa } \\
\text { et } \mathrm{al}^{17} \\
2009\end{array}$} & $\begin{array}{l}\text { Internal: Morse } \\
\text { taper with } \\
\text { antirotational } \\
\text { mechanism }\end{array}$ & $49.5 \pm 13.1$ & $27 / 37$ & NR & 117 & $\begin{array}{l}3.5 \text { and } 4.3 / 10 \\
11.5,13 \text { and } 15\end{array}$ & $\begin{array}{l}\text { Maxilla and } \\
\text { mandible }\end{array}$ & $\begin{array}{l}\text { Nobel } \\
\text { Biocare }\end{array}$ & $\begin{array}{l}\text { Single crowns, } \\
\text { fixed partial } \\
\text { prosthesis or } \\
\text { full-arch } \\
\text { prosthesis }\end{array}$ & $\begin{array}{l}\text { Screwed or } \\
\text { cemented }\end{array}$ & $\begin{array}{c}0.95 \\
( \pm 1.37) / 12\end{array}$ \\
\hline & $\begin{array}{l}\text { External: } \\
\text { Transmucosal } \\
\text { implant } \\
\text { with } \\
\text { antirotational } \\
\text { mechanism }\end{array}$ & $49.9 \pm 13.6$ & $32 / 21$ & NR & 82 & $\begin{array}{l}3.5 \text { and } 4.3 / 10 \\
11.5,13 \text { and } 15\end{array}$ & $\begin{array}{l}\text { Maxilla and } \\
\text { mandible }\end{array}$ & $\begin{array}{l}\text { Nobel } \\
\text { Biocare }\end{array}$ & $\begin{array}{l}\text { Single crowns, } \\
\text { fixed partial } \\
\text { prosthesis or } \\
\text { full-arch } \\
\text { prosthesis }\end{array}$ & $\begin{array}{l}\text { Screwed or } \\
\text { cemented }\end{array}$ & $\begin{array}{c}0.64 \\
( \pm 0.97) / 12\end{array}$ \\
\hline \multirow[t]{2}{*}{$\begin{array}{l}\text { Peñarrocha- } \\
\text { Diago } \\
\text { et al. }{ }^{14} 2013\end{array}$} & $\begin{array}{l}\text { Internal: Morse } \\
\text { taper }\end{array}$ & $56.9 \pm 7.8$ & $11 / 4$ & 0 & 72 & $\begin{array}{l}3.75 \text { and } 4.25 / \\
10,11.5 \text { and } 13\end{array}$ & $\begin{array}{l}\text { Maxilla and } \\
\text { mandible }\end{array}$ & Mozo-Grau & $\begin{array}{l}\text { Fixed full-arch } \\
\text { prosthesis, bar } \\
\text { overdentures or } \\
\text { Locator } \\
\text { overdentures }\end{array}$ & NR & $\begin{array}{c}0.12 \\
( \pm 0.17) / 12\end{array}$ \\
\hline & $\begin{array}{l}\text { External: } \\
\text { hexagon }\end{array}$ & & & & 69 & $\begin{array}{l}3.75 \text { and } 4.25 / \\
10,11.5 \text { and } 13\end{array}$ & $\begin{array}{l}\text { Maxilla and } \\
\text { mandible }\end{array}$ & Mozo-Grau & $\begin{array}{l}\text { Fixed full-arch } \\
\text { prosthesis, bar } \\
\text { overdentures or } \\
\text { Locator } \\
\text { overdentures }\end{array}$ & NR & $\begin{array}{c}0.38 \\
( \pm 0.51) / 12\end{array}$ \\
\hline \multirow{2}{*}{$\begin{array}{l}\text { Arnhart } \\
\text { et al }{ }^{18} \\
2012\end{array}$} & $\begin{array}{l}\text { External: } \\
\text { Transmucosal } \\
\text { implant } \\
\text { with } \\
\text { antirotational } \\
\text { mechanism }\end{array}$ & $49.9 \pm 13.6$ & $32 / 21$ & NR & 82 & $\begin{array}{l}3.5 \text { and } 4.3 / 10 \\
11.5,13 \text { and } 15\end{array}$ & $\begin{array}{l}\text { Maxilla and } \\
\text { mandible }\end{array}$ & $\begin{array}{l}\text { Nobel } \\
\text { Biocare }\end{array}$ & $\begin{array}{l}\text { Single crowns, } \\
\text { fixed partial } \\
\text { prosthesis or } \\
\text { full-arch } \\
\text { prosthesis }\end{array}$ & $\begin{array}{l}\text { Screwed or } \\
\text { cemented }\end{array}$ & $\begin{array}{c}0.16 \\
( \pm 1.06) / 36\end{array}$ \\
\hline & $\begin{array}{l}\text { Internal: Morse } \\
\text { taper }\end{array}$ & $46.9 \pm 14.6$ & $26 / 34$ & NR & 126 & $\begin{array}{l}3.5 \text { and } 4.3 / 8 \\
10,13 \text { and } 16\end{array}$ & $\begin{array}{l}\text { Maxilla and } \\
\text { mandible }\end{array}$ & $\begin{array}{l}\text { Nobel } \\
\text { Biocare }\end{array}$ & $\begin{array}{l}\text { Single crowns, } \\
\text { fixed partial } \\
\text { prosthesis or } \\
\text { full-arch } \\
\text { prosthesis }\end{array}$ & $\begin{array}{l}\text { Screwed or } \\
\text { cemented }\end{array}$ & $\begin{array}{c}0.85 \\
( \pm 1.32) / 36\end{array}$ \\
\hline \multirow[t]{2}{*}{$\begin{array}{l}\text { Koo et } \mathrm{al}^{7} \\
2012\end{array}$} & $\begin{array}{l}\text { External: } \\
\text { hexagon }\end{array}$ & 54.3 & $15 / 25$ & NR & 20 & $\begin{array}{c}4.3 / 8.5,10,11.5 \\
\text { and } 13\end{array}$ & $\begin{array}{l}\text { Maxilla and } \\
\text { mandible }\end{array}$ & NR & Single crowns & NR & $\begin{array}{c}0.29 \\
( \pm 0.35) / 12\end{array}$ \\
\hline & $\begin{array}{l}\text { Internal: } \\
\text { octagon }\end{array}$ & & & NR & 20 & $\begin{array}{l}4.3 / 8.5,10,11.5 \\
\text { and } 13\end{array}$ & $\begin{array}{l}\text { Maxilla and } \\
\text { mandible }\end{array}$ & NR & Single crowns & NR & $\begin{array}{c}0.07 \\
( \pm 0.21) / 12\end{array}$ \\
\hline \multirow{2}{*}{$\begin{array}{l}\text { Canullo } \\
\text { et al }\left.\right|^{2,8} \\
2012\end{array}$} & $\begin{array}{l}\text { External: } \\
\text { hexagon }\end{array}$ & 58.2 & $24 / 16$ & 0 & 40 & $4 / 13$ & Maxilla & $\begin{array}{l}\text { PI } \\
\text { Branemark }\end{array}$ & $\begin{array}{l}\text { Single 2-unit } \\
\text { prosthesis }\end{array}$ & Cemented & $\begin{array}{c}1.63 \\
18\end{array}$ \\
\hline & $\begin{array}{l}\text { Internal: Inward- } \\
\text { inclined } \\
\text { platform }\end{array}$ & & & 0 & 40 & $4 / 13$ & Maxilla & $\begin{array}{l}\mathrm{Pl} \\
\text { Branemark }\end{array}$ & $\begin{array}{l}\text { Single 2-unit } \\
\text { prosthesis }\end{array}$ & Cemented & $\begin{array}{c}0.49 \\
18\end{array}$ \\
\hline $\begin{array}{l}\text { Lin et al }{ }^{16} \\
2013\end{array}$ & $\begin{array}{l}\text { External: } \\
\text { hexagon }\end{array}$ & $47 \pm 11$ & $15 / 8$ & NR & 33 & $4-5 / 10-12$ & $\begin{array}{l}\text { Maxilla and } \\
\text { mandible }\end{array}$ & $\begin{array}{l}\text { Nobel } \\
\text { Biocare }\end{array}$ & $\begin{array}{l}\text { Single crown } \\
\text { and fixed 2-unit } \\
\text { prosthesis }\end{array}$ & Cemented & $\begin{array}{c}0.32 \\
( \pm 0.19) / 6\end{array}$ \\
\hline
\end{tabular}


Supplemental Table 1. (Continued) Data collected from studies evaluating marginal bone loss around implants with internal and external connections

\begin{tabular}{|c|c|c|c|c|c|c|c|c|c|c|c|}
\hline Study & $\begin{array}{c}\text { Type of } \\
\text { Connection }\end{array}$ & $\begin{array}{c}\text { Average } \\
( \pm S D) \text { age }\end{array}$ & $\begin{array}{c}\text { Males/ } \\
\text { Females }\end{array}$ & $\begin{array}{c}\text { Number } \\
\text { of Smokers } \\
(>10 \\
\text { Cigarettes/D) }\end{array}$ & $\begin{array}{c}\text { Number } \\
\text { of Implants }\end{array}$ & $\begin{array}{c}\text { Diameter/ } \\
\text { Length }(\mathbf{m m})\end{array}$ & Arch & Mfr & $\begin{array}{c}\text { Prosthesis } \\
\text { type }\end{array}$ & $\begin{array}{l}\text { Prothesis } \\
\text { retention }\end{array}$ & $\begin{array}{c}\text { Mean Bone } \\
\text { Loss }( \pm \text { SD) } \\
(\mathrm{mm}) / \\
\text { Follow-up } \\
\text { Period } \\
(\mathrm{mo})\end{array}$ \\
\hline & $\begin{array}{l}\text { Internal: Morse } \\
\text { taper }\end{array}$ & & $10 / 8$ & NR & 37 & $4-5 / 10-12$ & $\begin{array}{l}\text { Maxilla and } \\
\text { mandible }\end{array}$ & Friadent & $\begin{array}{l}\text { Single crown } \\
\text { and fixed 2-unit } \\
\text { prosthesis }\end{array}$ & Cemented & $\begin{array}{c}0.32 \\
( \pm 0.14) / 6\end{array}$ \\
\hline & $\begin{array}{l}\text { Internal: } \\
\text { octagon }\end{array}$ & & $10 / 12$ & NR & 33 & $4-5 / 10-12$ & $\begin{array}{l}\text { Maxilla and } \\
\text { mandible }\end{array}$ & Cowellmedi & $\begin{array}{l}\text { Single crown } \\
\text { and fixed 2-unit } \\
\text { prosthesis }\end{array}$ & Cemented & $\begin{array}{c}0.38 \\
( \pm 0.22) / 6\end{array}$ \\
\hline \multirow{2}{*}{$\begin{array}{l}\text { Pozzi } \\
\text { et al } \\
2014\end{array}$} & $\begin{array}{l}\text { Internal Morse } \\
\text { taper }\end{array}$ & $52.20 \pm 5.34$ & $15 / 19$ & 0 & 34 & $3.9 / 10$ and 13 & Mandible & $\begin{array}{l}\text { Nobel } \\
\text { Biocare }\end{array}$ & $\begin{array}{l}\text { Single crowns } \\
\text { CAD-CAM }\end{array}$ & Cemented & $\begin{array}{c}0.51 \\
( \pm 0.34) / 12\end{array}$ \\
\hline & $\begin{array}{l}\text { External: } \\
\text { hexagon }\end{array}$ & & & 0 & 34 & $4.1 / 10$ and 13 & Mandible & $\begin{array}{l}\text { Nobel } \\
\text { Biocare }\end{array}$ & $\begin{array}{l}\text { Single crowns } \\
\text { CAD-CAM }\end{array}$ & Cemented & $\begin{array}{c}1.10 \\
( \pm 0.52) / 12\end{array}$ \\
\hline \multirow{2}{*}{$\begin{array}{l}\text { Pozzi } \\
\text { et } \mathrm{al}^{4,13} \\
2014 \mathrm{a}\end{array}$} & $\begin{array}{l}\text { Internal Morse } \\
\text { taper }\end{array}$ & $52.20 \pm 5.34$ & $15 / 19$ & 0 & 34 & $\begin{array}{c}3.9 / 8.5,10,11.5 \\
\text { and } 13\end{array}$ & Mandible & $\begin{array}{l}\text { Nobel } \\
\text { Biocare }\end{array}$ & $\begin{array}{l}\text { Single crowns } \\
\text { CAD-CAM }\end{array}$ & Cemented & $\begin{array}{c}0.67 \\
( \pm 0.39) / 36\end{array}$ \\
\hline & $\begin{array}{l}\text { External: } \\
\text { hexagon }\end{array}$ & & & 0 & 34 & $\begin{array}{c}4.1 / 8.5,10,11.5 \\
\text { and } 13\end{array}$ & Mandible & $\begin{array}{l}\text { Nobel } \\
\text { Biocare }\end{array}$ & $\begin{array}{l}\text { Single crowns } \\
\text { CAD-CAM }\end{array}$ & Cemented & $\begin{array}{c}1.24 \\
( \pm 0.47) / 36\end{array}$ \\
\hline
\end{tabular}

NR, not reported.

Supplemental Table 2. Data collected from study evaluating marginal bone loss around implants with external connections

\begin{tabular}{|c|c|c|c|c|c|c|c|c|c|c|c|}
\hline Study & Type of Connection & $\begin{array}{c}\text { Average } \\
( \pm \text { SD) age }\end{array}$ & $\begin{array}{c}\text { Males/ } \\
\text { Females }\end{array}$ & $\begin{array}{c}\text { Number of } \\
\text { Smokers (>10 } \\
\text { Cigarettes/D) }\end{array}$ & $\begin{array}{l}\text { Number of } \\
\text { Implants }\end{array}$ & $\begin{array}{c}\text { Diameter/ } \\
\text { length }(\mathbf{m m})\end{array}$ & Arch & Mfr & $\begin{array}{l}\text { Prosthesis } \\
\text { Type }\end{array}$ & $\begin{array}{l}\text { Prosthesis } \\
\text { Retention }\end{array}$ & $\begin{array}{c}\text { Mean Bone Loss } \\
\text { ( } \pm \text { SD) } \\
\text { (mm)/Follow-up } \\
\text { Period (mo) }\end{array}$ \\
\hline \multirow[t]{2}{*}{$\begin{array}{l}\text { Vandeweghe } \\
\text { and De Bruyn } \\
2012\end{array}$} & $\begin{array}{l}\text { External: hexagon with } \\
\text { platform switching }\end{array}$ & $57 \pm 13$ & $9 / 6$ & 0 & 15 & $7 / 9$ & $\begin{array}{l}\text { Maxilla and } \\
\text { mandible }\end{array}$ & NR & $\begin{array}{l}\text { Single } \\
\text { CAD-CAM } \\
\text { crowns }\end{array}$ & NR & $0.66( \pm 0.47) / 12$ \\
\hline & $\begin{array}{l}\text { External: hexagon } \\
\text { without platform } \\
\text { switching }\end{array}$ & & & & & & & & & NR & $0.94( \pm 0.42) / 12$ \\
\hline
\end{tabular}

CAD-CAM, computer-aided design and computer-aided manufacture; NR, not reported. 
Supplemental Table 3. Data collected from studies evaluating marginal bone loss around implants with internal connections

\begin{tabular}{|c|c|c|c|c|c|c|c|c|c|c|c|}
\hline Study & $\begin{array}{c}\text { Type of } \\
\text { Connection }\end{array}$ & $\begin{array}{c}\text { Average } \\
\text { ( } \pm \text { SD) } \\
\text { age }\end{array}$ & $\begin{array}{c}\text { Males/ } \\
\text { Females }\end{array}$ & $\begin{array}{c}\text { Number of } \\
\text { Smokers } \\
(>10 \\
\text { Cigarettes/D) }\end{array}$ & $\begin{array}{l}\text { Number of } \\
\text { Implants }\end{array}$ & $\begin{array}{l}\text { Diameter/ } \\
\text { length }(\mathbf{m m})\end{array}$ & Arch & Mfr & $\begin{array}{l}\text { Prosthesis } \\
\text { type }\end{array}$ & $\begin{array}{l}\text { Prosthesis } \\
\text { retention }\end{array}$ & $\begin{array}{c}\text { Mean Bone } \\
\text { Loss }( \pm \text { SD) } \\
(\mathrm{mm}) / \\
\text { Follow-up } \\
\text { Period } \\
(\mathrm{mo})\end{array}$ \\
\hline $\begin{array}{l}\text { Chou } \\
\text { et } \mathrm{al}^{2} \\
2004\end{array}$ & $\begin{array}{l}\text { Internal: } \\
\text { Morse taper }\end{array}$ & $N R$ & NR & NR & 1500 & NR & $\begin{array}{l}\text { Maxilla and } \\
\text { mandible }\end{array}$ & $\begin{array}{l}\text { Ankylos- } \\
\text { Dentsply }\end{array}$ & $\begin{array}{l}\text { Single } \\
\text { crowns, } \\
\text { fixed partial } \\
\text { prosthesis } \\
\text { or full-arch } \\
\text { prosthesis }\end{array}$ & NR & $0.64 / 36$ \\
\hline \multirow[t]{2}{*}{ 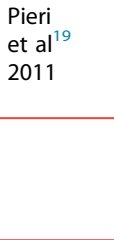 } & $\begin{array}{l}\text { Internal } \\
\text { Morse taper } \\
\text { (platform } \\
\text { switching) }\end{array}$ & 45.8 & $7 / 13$ & 18 & 20 & NR & Maxilla & NR & $\begin{array}{l}\text { All-ceramic } \\
\text { or metal- } \\
\text { ceramic } \\
\text { crowns }\end{array}$ & Cemented & $\begin{array}{c}0.19 \\
( \pm 0.17) / 12\end{array}$ \\
\hline & $\begin{array}{l}\text { Internal NR } \\
\text { (Without } \\
\text { Platform } \\
\text { Switching) }\end{array}$ & 46.6 & $8 / 12$ & 19 & 20 & NR & Maxilla & NR & $\begin{array}{l}\text { All-ceramic } \\
\text { or metal- } \\
\text { ceramic } \\
\text { crowns }\end{array}$ & Cemented & $\begin{array}{c}0.49 \\
( \pm 0.25) / 12\end{array}$ \\
\hline \multirow[t]{2}{*}{$\begin{array}{l}\text { Gultekin } \\
\text { et } \text { al }^{20} \\
2013\end{array}$} & $\begin{array}{l}\text { Internal } \\
\text { Trichannel } \\
\text { connection }\end{array}$ & 41.3 & $5 / 20$ & 0 & 50 & $\begin{array}{l}\text { At least } 3.5 \text { in } \\
\text { diameter and } \\
8 \text { in length }\end{array}$ & $\begin{array}{l}\text { Maxilla and } \\
\text { mandible }\end{array}$ & $\begin{array}{l}\text { Nobel } \\
\text { Biocare }\end{array}$ & $\begin{array}{l}\text { Metal- } \\
\text { ceramic } \\
\text { crowns }\end{array}$ & Cemented & $\begin{array}{c}0.83 \\
( \pm 0.16) / 12\end{array}$ \\
\hline & $\begin{array}{l}\text { Internal } \\
\text { Morse taper }\end{array}$ & & & 0 & 43 & $\begin{array}{l}\text { At least } 3.5 \text { in } \\
\text { diameter and } \\
8 \text { in length }\end{array}$ & $\begin{array}{l}\text { Maxilla and } \\
\text { mandible }\end{array}$ & NR & $\begin{array}{l}\text { Metal- } \\
\text { ceramic } \\
\text { crowns }\end{array}$ & Cemented & $\begin{array}{c}0.35 \\
( \pm 0.13) / 12\end{array}$ \\
\hline \multirow[t]{2}{*}{$\begin{array}{l}\text { Jo et } \mathrm{al}^{12} \\
2014\end{array}$} & Internal NR & 56.4 & $15 / 9$ & NR & $\begin{array}{l}20 \text { (inter-implant } \\
\text { distance } \leq 3 \mathrm{~mm} \text { ) }\end{array}$ & NR & $\begin{array}{l}\text { Maxilla and } \\
\text { mandible }\end{array}$ & NR & $\begin{array}{l}\text { Fixed 2-unit } \\
\text { prosthesis }\end{array}$ & NR & $\begin{array}{c}0.15 \\
( \pm 0.18) / 12 \\
\end{array}$ \\
\hline & & & & & $\begin{array}{l}30 \text { (inter-implant } \\
\text { distance } \geq 3 \mathrm{~mm} \text { ) }\end{array}$ & NR & $\begin{array}{l}\text { Maxilla and } \\
\text { mandible }\end{array}$ & NR & $\begin{array}{l}\text { Fixed 2-unit } \\
\text { prosthesis }\end{array}$ & NR & $\begin{array}{c}0.11( \pm 0.33) \\
12\end{array}$ \\
\hline $\begin{array}{l}\text { Meyler } \\
\text { et } \text { al }^{40} \\
2014\end{array}$ & $\begin{array}{l}\text { Internal: } \\
\text { hexagon }\end{array}$ & 48.7 & $9 / 11$ & 0 & 54 & $\begin{array}{l}3.8,4.5 \text { and } \\
5.5 / 10,11,13 \\
\text { and } 15\end{array}$ & $\begin{array}{l}\text { Maxilla and } \\
\text { mandible }\end{array}$ & Dentsply & $\begin{array}{l}\text { Single } \\
\text { crowns }\end{array}$ & Cemented & $\begin{array}{c}0.63( \pm 0.26) \\
\text { (Mesial site) } \\
0.56( \pm 0.25) \\
\text { (Distal site) } \\
120\end{array}$ \\
\hline $\begin{array}{l}\text { Calvo- } \\
\text { Guirado } \\
\text { et } \mathrm{al}^{5} \\
2014\end{array}$ & Internal: NR & $\begin{array}{l}37.85 \\
\pm 7.09\end{array}$ & $30 / 23$ & NR & 71 & $\begin{array}{l}4.2 \text { and } 5 / 11.5 \\
\text { and } 13\end{array}$ & Maxilla & $\begin{array}{l}\text { MIS- } \\
\text { Implants }\end{array}$ & $\begin{array}{l}\text { Single } \\
\text { crowns }\end{array}$ & NR & $\begin{array}{c}0.86 \\
( \pm 0.29) / 36\end{array}$ \\
\hline
\end{tabular}

NR, not reported. 
Supplemental Table 4. Marginal bone loss for each period evaluated by studies

\begin{tabular}{|c|c|c|c|c|c|c|c|c|c|c|c|}
\hline \multirow[b]{2}{*}{ Study } & \multirow[b]{2}{*}{$\begin{array}{c}\text { Type of } \\
\text { Connection }\end{array}$} & \multirow{2}{*}{$\begin{array}{l}\text { Mean Bone } \\
\text { Loss ( } \pm \text { SD) in } \\
\text { mm Between } \\
\text { Implant } \\
\text { Installation to } \\
\text { Prosthesis } \\
\text { Installation }\end{array}$} & \multicolumn{9}{|c|}{ Mean Bone Loss $( \pm S D)$ in $\mathrm{mm}$ for the Period Shown (mo) } \\
\hline & & & 3 & 4 & 6 & 12 & 18 & 24 & 36 & 60 & 120 \\
\hline $\begin{array}{l}\text { Chou et } \mathrm{al}^{2} \\
2004\end{array}$ & $\begin{array}{l}\text { Internal: Morse } \\
\text { taper }\end{array}$ & 0.81 & - & - & - & 0.15 & - & 0.48 & 0.64 & - & - \\
\hline \multirow[t]{3}{*}{$\begin{array}{l}\text { Kielbassa } \\
\text { et al }{ }^{17} 2009 ; \\
\text { Arnhart et al }^{18} \\
2012\end{array}$} & $\begin{array}{l}\text { Internal: Morse } \\
\text { taper with } \\
\text { antirotational } \\
\text { mechanism }\end{array}$ & NR & - & - & - & $0.95( \pm 1.37)$ & - & - & $0.89( \pm 1.65)$ & - & - \\
\hline & $\begin{array}{l}\text { External: } \\
\text { Transmucosal } \\
\text { implant with } \\
\text { antirotational } \\
\text { mechanism }\end{array}$ & NR & - & - & - & $0.64( \pm 0.97)$ & - & - & $0.16( \pm 1.06)$ & - & - \\
\hline & $\begin{array}{l}\text { Internal: Morse } \\
\text { taper }\end{array}$ & NR & - & - & - & $0.63( \pm 1.17)$ & - & - & $0.85( \pm 1.32)$ & - & - \\
\hline \multirow[t]{2}{*}{$\begin{array}{l}\text { Crespi et al }{ }^{15} \\
2009\end{array}$} & $\begin{array}{l}\text { External: } \\
\text { hexagon }\end{array}$ & $\begin{array}{l}\text { Immediate } \\
\text { loading }\end{array}$ & - & - & - & $0.82( \pm 0.40)$ & - & $0.78( \pm 0.49)$ & - & - & - \\
\hline & $\begin{array}{l}\text { Internal: Morse } \\
\text { taper }\end{array}$ & $\begin{array}{l}\text { Immediate } \\
\text { loading }\end{array}$ & - & - & - & $0.78( \pm 0.45)$ & - & $0.73( \pm 0.52)$ & - & - & - \\
\hline \multirow[t]{2}{*}{$\begin{array}{l}\text { Pieri et al }{ }^{19} \\
2011\end{array}$} & $\begin{array}{l}\text { Internal: Morse } \\
\text { taper }\end{array}$ & $\begin{array}{l}\text { Immediate } \\
\text { loading }\end{array}$ & - & $0.08( \pm 0.1)$ & - & $0.19( \pm 0.17)$ & - & - & - & - & - \\
\hline & Internal: NR & $\begin{array}{l}\text { Immediate } \\
\text { loading }\end{array}$ & - & $0.22( \pm 0.16)$ & - & $0.49( \pm \pm 0.25)$ & - & - & - & - & - \\
\hline \multirow{2}{*}{$\begin{array}{l}\text { Peñarrocha- } \\
\text { Diago et al } \\
2013\end{array}$} & $\begin{array}{l}\text { Internal: Morse } \\
\text { taper }\end{array}$ & $0.05(0.11)$ & - & - & $0.07(0.13)$ & $0.12( \pm 0.17)$ & - & - & - & - & - \\
\hline & $\begin{array}{l}\text { External: } \\
\text { hexagon }\end{array}$ & $0.16(0.31)$ & - & - & $0.27(0.43)$ & $0.38(0.51)$ & - & - & - & - & - \\
\hline \multirow[t]{2}{*}{$\begin{array}{l}\text { Koo et } \mathrm{al}^{7} \\
2012\end{array}$} & $\begin{array}{l}\text { External: } \\
\text { hexagon }\end{array}$ & $0.61(0.37)$ & - & - & - & $0.29(0.35)$ & - & - & - & - & - \\
\hline & $\begin{array}{l}\text { Internal: } \\
\text { octagon }\end{array}$ & $0.08(0.30)$ & - & - & - & $-0.07(0.21)$ & - & - & - & - & - \\
\hline \multirow[t]{2}{*}{$\begin{array}{l}\text { Vandeweghe } \\
\text { and De } \\
\text { Bruyn }^{6} 2012\end{array}$} & $\begin{array}{l}\text { External: } \\
\text { hexagon with } \\
\text { platform } \\
\text { switching }\end{array}$ & $\begin{array}{l}\text { Immediate } \\
\text { loading }\end{array}$ & $0.28( \pm 0.3)$ & - & $0.64( \pm 0.63)$ & $0.66( \pm 0.47)$ & - & - & - & - & - \\
\hline & $\begin{array}{l}\text { External: } \\
\text { hexagon } \\
\text { without } \\
\text { platform } \\
\text { switching }\end{array}$ & $\begin{array}{l}\text { Immediate } \\
\text { loading }\end{array}$ & $0.51( \pm 0.4)$ & - & $1.05( \pm 0.61)$ & $0.94( \pm 0.42)$ & - & - & - & - & - \\
\hline \multirow[t]{2}{*}{$\begin{array}{l}\text { Canullo et } \text { al }^{8} \\
2012\end{array}$} & $\begin{array}{l}\text { External: } \\
\text { hexagon }\end{array}$ & NR & - & - & $\sim 1.0$ & $\sim 1.45$ & 1.63 & - & - & - & - \\
\hline & $\begin{array}{l}\text { Internal: } \\
\text { inward-inclined } \\
\text { platform }\end{array}$ & NR & - & - & $\sim 0.25$ & $\sim 0.35$ & 0.49 & - & - & - & - \\
\hline \multirow[t]{3}{*}{$\begin{array}{l}\text { Lin et } \text { al }^{16} \\
2013\end{array}$} & $\begin{array}{l}\text { External: } \\
\text { hexagon }\end{array}$ & $0.45( \pm 0.19)$ & $0.21( \pm 0.13)$ & - & $0.32( \pm 0.19)$ & - & - & - & - & - & - \\
\hline & $\begin{array}{l}\text { Internal: Morse } \\
\text { taper }\end{array}$ & $0.38( \pm 0.19)$ & $0.19( \pm 0.11)$ & - & $0.32( \pm 0.14)$ & - & - & - & - & - & - \\
\hline & $\begin{array}{l}\text { Internal: } \\
\text { octagon }\end{array}$ & $0.44( \pm 0.15)$ & $0.18( \pm 0.12)$ & - & $0.38( \pm 0.22)$ & - & - & - & - & - & - \\
\hline \multirow[t]{2}{*}{$\begin{array}{l}\text { Gultekin } \\
\text { et } \mathrm{al}^{20} 2013\end{array}$} & $\begin{array}{l}\text { Internal: } \\
\text { trichannel } \\
\text { connection }\end{array}$ & $0.24( \pm 0.14)$ & - & - & - & $0.83( \pm 0.16)$ & - & - & - & - & - \\
\hline & $\begin{array}{l}\text { Internal: Morse } \\
\text { taper }\end{array}$ & $0.22( \pm 0.11)$ & - & - & - & $0.35( \pm 0.13)$ & - & - & - & - & - \\
\hline $\begin{array}{l}\text { Pozzi et } \text { al }^{4,13} \\
2014\end{array}$ & $\begin{array}{l}\text { Internal: Morse } \\
\text { taper }\end{array}$ & $0.37( \pm 0.23)$ & - & - & - & $0.51( \pm 0.34)$ & - & - & $0.67( \pm 0.39)$ & - & - \\
\hline
\end{tabular}


Supplemental Table 4. (Continued) Marginal bone loss for each period evaluated by studies

\begin{tabular}{|c|c|c|c|c|c|c|c|c|c|c|c|}
\hline \multirow[b]{2}{*}{ Study } & \multirow{2}{*}{$\begin{array}{c}\text { Type of } \\
\text { Connection }\end{array}$} & \multirow{2}{*}{$\begin{array}{l}\text { Mean Bone } \\
\text { Loss ( } \pm \text { SD) in } \\
\text { mm Between } \\
\text { Implant } \\
\text { Installation to } \\
\text { Prosthesis } \\
\text { Installation }\end{array}$} & \multicolumn{9}{|c|}{ Mean Bone Loss $( \pm \mathrm{SD})$ in $\mathrm{mm}$ for the Period Shown $(\mathrm{mo})$} \\
\hline & & & 3 & 4 & 6 & 12 & 18 & 24 & 36 & 60 & 120 \\
\hline & $\begin{array}{l}\text { External: } \\
\text { hexagon }\end{array}$ & $0.95( \pm 0.56)$ & - & - & - & $1.10( \pm 0.52)$ & - & - & $1.24( \pm 0.47)$ & - & - \\
\hline $\begin{array}{l}\text { Calvo-Guirado } \\
\text { et } \mathrm{al}^{5} 2014\end{array}$ & Internal: NR & $\begin{array}{l}\text { Immediate } \\
\text { loading }\end{array}$ & - & - & - & $0.67( \pm 0.21)$ & - & $0.79( \pm 0.23)$ & $0.86( \pm 0.29)$ & - & - \\
\hline $\begin{array}{l}\text { Meyle et al }{ }^{40} \\
2014\end{array}$ & $\begin{array}{l}\text { Internal: } \\
\text { hexagon }\end{array}$ & $\begin{array}{l}\text { Immediate } \\
\text { loading }\end{array}$ & - & - & - & - & - & - & - & $\begin{array}{l}0.16( \pm 0.1) \\
\text { (mesial site) } \\
0.23( \pm 0.34) \\
\text { (distal site) }\end{array}$ & $\begin{array}{l}0.63( \pm 0.26) \\
\text { (mesial site) } \\
0.56( \pm 0.25) \\
\text { (distal site) }\end{array}$ \\
\hline
\end{tabular}

NR, not reported. 